\title{
Eye Drops, Prolonged Release Dosage
}

\section{Form}

National Cancer Institute

\section{Source}

National Cancer Institute. Eye Drops, Prolonged Release Dosage Form. NCI Thesaurus.

Code C149504.

Liquid sterile single-dose or multidose preparation intended for ocular use. The active substance is released over an extended period of time. 